\title{
SISTEM PENGAMANAN MESIN ATM DENGAN MENGGUNAKAN PENGENALAN SIDIK JARI DAN WAJAH FACE RECOGNITION UNTUK MEMINIMALISIR CYBERBANKING CRIME
}

\author{
Mohamad Arifin \\ Universitas Airlangga \\ mohamad.arifin-2014@fisip.unair.ac.id
}

\begin{abstract}
Mesin anjungan tunai mandiri (ATM) sangat mudahkan para nasabah perbankan dalam bertransaksi perbankan selama 24 jam tanpa terikat dengan jam operasional kantor bank. Nasabah cukup dengan menggunakan kartu dan memasukan nomor pin pada mesin, nasabah dapat bertransaksi non tunai dan penarikan uang. Tetapi, kelemahan mesin ATM yang menggunakan kartu sangat rawan peretasan. Biasanya, peretasan data nasabah menggunakan alat skimmer yang terpasang pada slot card mesin. Alat skimmer berfungsi untuk mencuri data nasabah termasuk nomor rekening, jumlah saldo dan nomor PIN yang tersimpan pada pita electronic magnetic (berada di bagian belakang kartu). Data nasabah yang terekam dapat digunakan para hacker untuk menngandakan kartu nasabah dan mengambil uang nasabah dengan kartu atm duplikat. Tindakan haker tersebut sangat merugikan nasabah. Oleh sebab itu, diperlukan pengamanan mesin ATM yang bersifat biometric atau melekat pada diri manusia yaitu sidik jari dan wajah. Hal tersebut karena bentuk atau pola sidik jari manusia tidak sama antara satu individu dengan lainnya, begitu juga dengan wajah yang memiliki tingkat akurasi yang tinggi. Metode dalam penelitian terbagi dua yaitu pengumpulan data pendukung melalui studi literature tentang topik terkait dan selanjutnya perancangan grafis prototype mesin ATM dengan menggunakan pengenalan sidik jari dan wajah. Cara operasional yang dilakukan, nasabah melakukan perekaman sidik jari dan wajah ke kantor bank. Selanjutnya, petugas bank menvalidasi dengan data kependudukan yang memuat informasi biometrics nasabah. Jika sudah tervalidasi lalu petugas bank mensikronisasikan dengan rekening nasabah dan proses selesai. Nasabah dapat bertransaksi pada mesin ATM tanpa menggunakan kartu ATM. Cukup melakukan verifikasi sidik jari dan wajah pada mesin adapun output dari penelitian ini untuk meminimilisir tingkat kejahatan cyberbanking.
\end{abstract}

Keywords: Mesin ATM, Sidik Jari, Wajah

Received 24 February 2021 Accepted 31 January 2022

\section{INTRODUCTION}

Kejahatan perbankan Indonesia khususnya peretasan kartu ATM (Anjungan Tunai Mandiri) dari tahun ke tahun memiliki tren prevelensi yang cukup tinggi dan diperkuat dengan data persebaran kasus pembobolan ATM dengan modus skimming atau meretas data nasabah melalui alat skimmer yang terpasang pada mesin atm. Jumlah kasus peretasan ATM paling banyak pada bank BCA tahun 2015 dan bank BRI tahun 2016. Pada kasus bank BCA tahun 2015 total korban nasabah adalah 112 rekening [1] sedangkan korban dari kejahatan skimming pada bank BRI tahun 2016 di kantor cabang Mataram provinsi Lombok sebanyak 515 rekening dan mengalami kerugian paling besar sebanyak 2,7 M [2]. Selain itu, juga terjadi kasus skimming pada bank Mandiri pada tahun 2018 yang terjadi di dua tempat sekaligus, yaitu Surabaya dan 
Jogja, dengan jumlah korban 141 nasabah. Dari tahun 2011 sampai dengan tahun 2017, kasus skimming terus meningkat. Pada tahun 2015, kasus skimming ATM di indonesia tercatat sebanyak 1.549 kasus atau $1 / 3$ dari kasus skimming di dunia [3].

Sistem pengamanan berbasis biometrics menggunakan sidik jari sangat efektif untuk diterapkan untuk sistem keamanan kendaraan bermotor karena memiliki tingkat akurasi yang sangat tinggi dan tidak mudah dipalsukan karena pola sidik jari tidak memiliki kesamaan atau kemiripan antara individu satu dengan individu lain walaupun kembar indetik, dikarenakan pola sidik jari terbentuk saat trimester pertama kehamilan [4]. Selain itu fungsi lain sidik jari dapat diterapkan untuk mesin absensi elektronik menggantikan metode konvensional melalui tanda tangan yang mudah dipalsukan dengan menggunakan sistem absensi menggunakan sidik jari juga memudahkan pihak personalia memantau kedisplinan dalam hal kehadiran pegawai secara realtime dan memiliki tingkat akurasi sebesar 90 persen yang berguna untuk pertimbangan pemberian reward maupun punishment bagi pegawai yang bersangkutan [5]. Manfaat lain sidik jari dalam kehidupan dapat dimanfaatkan untuk mendeteksi penyakit kanker payudara dapat di deteksi melalui sidik jari dengan menggunakan analisis pola sudut ATD phalanx distal yang ada pada garis tangan manusia. Dengan menunjukan hasil bahwa sudut ATD antara penderita kanker payudara dan non penderita kanker payudara tidak memiliki kecenderungan yang signifikant namun memiliki kecenderugan pola sidik jari yaitu pola whorl pada penderita kanker payudara [6].

Selain sidik jari biometrics manusia yang dapat diterapkan untuk sistem keamanan dengan memiliki tingkat akurasi yang sangat tinggi yaitu dengan verifikasi wajah atau lebih dikenal dengan istilah face recogntion yang merupakan sebuah metode analisis wajah berdasarkan karakteristik ukuran kepala, bentuk iris mata, hidung, bibir bentuk rambut yang dipengaruhi unsur genetics dan ras karena yang menyebabkan bentuk wajah manusia memiliki karakteristik berbeda antar individu dengan individu yang lain [7] yang telah diterapkan untuk untuk membantu aparat kepolisian dalam mengungkap kasus kriminalitas dengan menggunakan teknologi kamera CCTV circuit closed television yang telah di integrasikan database kependudukan nasional. Dalam sistem kartu penduduk elektronik (E-KTP) telah memuat informasi biologis mulai wajah, kornea mata, dan sidik jari yang memudahkan dalam pengungkapan kasus kriminalitas. Teknologi pengenalan face reconigtion juga diterapkan dalam sistem kunci otomatis smartphone karena lebih mengutamakan privasi pengguna akan data data pribadi yang tersimpan pada smartphone [8]. Disamping itu sistem keamanan berbasis verifikasi wajah juga dapat diterapkan sistem keamanan ponsel pintar atau smartphone berbasis face recognition dan untuk keamanan pintu rumah dan kantor untuk mencegah tindakan kriminalitas pencurian dan meminimalisir kunci hilang atau ketinggalan. dengan menggunakan kamera webcam sebagai sensor pendeteksi dan media pengambilan gambar wajah untuk input yang akan diolah menggunakan metode Grayscale pada mini PC mendeteksi wajah manusia dan mengambil gambar yang nantinya akan djadikan sampel untuk pengenalan wajah dan untuk sampel database [9]. Secara umum proses indetifikasi wajah secara umum memiliki step by step sebagai berikut:

1. Capturing / pengambilan gambar subjek melakukan perekaman wajah menggunakan camera beresolusi tinggi agar mudah untuk dikenali oleh sistem

2. Extracting / Pengolahan : wajah yang telah terekam masuk dalam bank data untuk di verifikasi dengan data kependudukan selanjutnya di simpan.

3. Comparing / Klasifikasi : proses ini bertujuan untuk memverifikasi apakah andanya kemiripan wajah individu satu dengan individu lain tujuanya untuk

4. Matching / Pengenalan : merupakan tahap akhir yaitu proses pengenalan wajah bagi individu yang telah melakukan perekaman akan diterima oleh sistem sebaliknya individu yang belum melakukan perekaman sistem akan di tolak sistem otomatis 


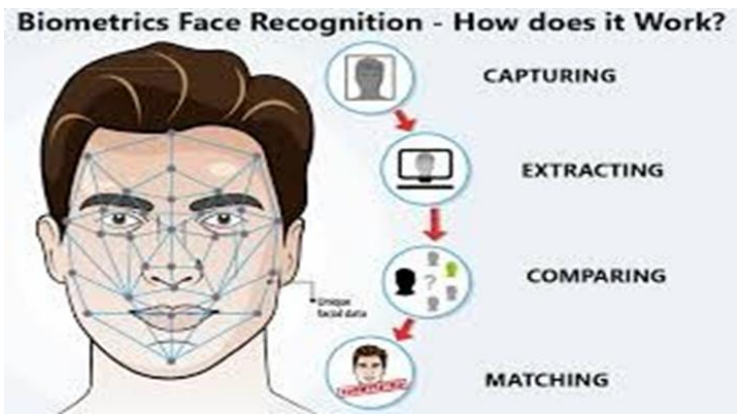

Gambar 1. Ilustrasi Proses Identifikasi Menggunakan Face Recognition

Metode lain yang akurat untuk pengenalan wajah dengan menggunakan Histogram of Oriented Gradient (HOG) yang dapat melakukan verifikasi wajah. Berdasarkan histogram lokal dari orientasi gradien yang diberi bobot dengan magnitude gradien [10]. Dari setiap individu yang di jadikan sampel dan hasil pengujian sampel menggunakan metode tersebut menunjukan tingkat akurasi pengenalan wajah dengan prevelensi keberhasilan tinggi dengan rata-rata akurasi sebesar $80 \%$. Selain metode Histogram of oriented Gradient untuk pengenalan wajah ada metode kedua yang serupa yang dikembangkan dengan menggunakan sistem algoritma yang lebih berfokus pada estimasi identifikasi ras pada manusia. Dengan cara kerja mengidentifikasi ciri-ciri wajah individu dari berbagai ras yang telah tersimpan sebelumnya dalam database kemudian citra wajah tersebut diekstrak menggunakan metode DCT (Discrete Cosine Transform) dan diklasifikasikan menggunakan metode decision tree. Dari hasil proses tersebut menghasilkan pengelompokan citra wajah berdasarkan klasifikasi ras yang berfungsi sebagai acuan yang akan digunakan untuk memprediksi ras dari individu pada citra wajah masukan sistem output dari sistem ini sangat membantu dalam bidang forensic untuk mengidentifikasi jenazah yang sudah hancur dari korban kecelakaan massal seperti pesawat, kapal,

Fungsi lain pengenalan wajah dapat dimplementasikan sebagai keamanan folder yang ada pada komputer atu laptop yang sangat rawan dicuri data data yang bersifat penting dan pribadi oleh orang lain [11]. Terlebih jika komputer kantor yang di gunakan bersama yang memiliki kemungkinan terjadi pembobolan atau peretasan file dan disalahgunakan oleh orang orang tak bertanggung jawab. Hal ini sangat merugikan pemilik asli file tersebut jika data diretas data sangat penting atau urgent. Oleh sebab itu perlu di tambahkan fitur keamanan tambahan yaitu biometrik pengenalan wajah dengan alasan karena ciri - ciri fisik wajah manusia memiliki karakteristik yang berbeda - beda yang selalu melekat pada manusia.

\section{RESEARCH METHODS}

Metode yang digunakan dalam penelitian ini dikelompokan menjadi beberapa komponen antara lain: yang pertama pengumpulan data dengan menggunakan data sekunder yang bersumber dari penelitian terdahulu yang terkait dengan data jumlah kejahatan peretasan data nasabah menjadi korban debit card fraud crime pada beberapa bank yang ada di Indonesia. Selanjutnya, dianalisis dengan menggunakan statistik deskriptif pengambilan sampel penelitian ini menggunakan metode stratified purposive sampling dengan alasan untuk mengetahui jumlah kerugian yang dialami oleh pihak perbankan yang disebabkan oleh kejahatan debit fraud crime yang menggunakan media perantara mesin anjungan tunai mandiri. Kemudian di analisis dengan menggunakan analisis deskritip dan tahap akhir dilakukan perancangan prototype / rancang bangun re-design mesin ATM menggunakan sistem pengenalan sidik jari dan wajah dengan agar memudahkan bagi para pembaca untuk memahami cara kerja sistem operasional mesin ATM dengan menggunakan sidik jari an pengenalan wajah 


\section{FINDINGS AND DISCUSSION}

\section{Jumlah Kasus Peretasan dan kerugian yang dialami perbankan}

Tabel 1. Data Kerugian yang Dialami Perbankan akibat Peretasan ATM Periode Tahun 20152019

\begin{tabular}{|l|l|r|l|c|}
\hline No & Nama Bank & $\begin{array}{c}\text { Total Kerugian } \\
\text { (WR) }\end{array}$ & Lokasi kejadian & Tahun \\
\hline 1 & Bank BNI & 50.000 .000 & Bali & 2019 \\
\hline 2 & Bank Central Asia & 300.000 .000 & Jakarta Selatan & 2019 \\
\hline 3 & Bank BRI & 145.000 .000 & Kediri & 2018 \\
\hline 4 & Bank Mandiri & 260.000 .000 & Surabaya & 2018 \\
\hline 5 & Bank Mandiri & 260.000 .000 & Yogyakarta & 2018 \\
\hline 6 & Bank BRI & 2.700 .000 .000 .000 & Lombok & 2016 \\
\hline 7 & Bank Central Asia & 1.250 .000 .000 .000 & Jakarta Bandung & 2015 \\
\hline
\end{tabular}

Sum ber: Adm in (2016); Deny (2016); danH akim (2016)

Dari data di atas di dapatkan prevelensi kerugian yang significant yaitu jumlah kasus paling tinggi pada kisaran tahun 2015-2016 pada bank BRI wilayah Lombok provinsi Nusa Tenggara Barat dengan total kerugian dari peretasan kartu ATM nasabah sebesar IDR 2.700.000.000.000 dan Bank Central Asia wilayah Jakarta dan Bandung sebesar IDR.1.250.000.000.000. Sedangkan prevelensi kasus peretasan ATM nasabah terendah pada tahun 2018-2019 pada peringkat pertama bank BNI wilayah Bali sebesar IDR 50.000.000 kemudian peringkat kedua oleh bank BRI wilayah kediri sebesar IDR 145.000.000 serta perinngkat ketiga ada pada mandiri wilayah Yogyakarta dan Surabaya pada tahun 2018 dengan jumlah relatif hampir IDR 260.000.000.

Tabel 2. Data Jumlah Kasus Peretasan kartu ATM Nasabah Berdasarkan Jenis Bank Periode Tahun 2015-2019

\begin{tabular}{|l|l|l|r|}
\hline No & Nama Bank & Jumlah Kasus & Tahun \\
\hline 1 & Bank BCA & 115 Rekening Nasabah & 2015 \\
\hline 2 & Bank BRI & 515 Rekening Nasabah & 2016 \\
\hline 3 & Bank Mandiri & 141 Rekening Nasabah & 2018 \\
\hline 4 & Bank BNI & 141 Rekening Nasabah & 2019 \\
\hline
\end{tabular}

Sum ber: Kom pas.com (2019), Supriyatin (2015), dan Yudistira (2018)

Dari pemamparan data di atas pada tahun 2016 merupakan prevelensi kasus peretasan kartu ATM nasabah perbankan yang tertinggi yang ada bank BRI sebagai peringkat pertama dengan jumlah korban sebesar 515 rekening nasabah. Kemudian disusul peringkat kedua bank BCA dengan jumlah 115 rekening nasabah pada tahun 2015. Peringkat ketiga dan keempat ada bank mandiri dan BNI dengan jumlah kasus relatif sama yaitu 141 Rekening nasabah pada tahun 2018 dan 2019. 


\section{Data Pengguna Alat Pembayaaran Metode Kartu}

Tabel 3. Pengguna APMK

\begin{tabular}{|l|c|c|c|c|c|c|}
\hline Jenis & T ahun & T ahun & T ahun & T ahun & T ahun & T ahun \\
Kartu & $\mathbf{2 0 1 4}$ & $\mathbf{2 0 1 5}$ & $\mathbf{2 0 1 6}$ & $\mathbf{2 0 1 7}$ & $\mathbf{2 0 1 8}$ & 2019 \\
\hline $\begin{array}{l}\text { Kartu } \\
\text { Kredit }\end{array}$ & 16.043 .347 & 16.863 .842 & 17.406 .327 & 17.244 .127 & 17.275 .128 & 17.487 .057 \\
\hline Kartu & 7.189 .917 & 7.330 .388 & 8.361 .351 & 8.815 .007 & 8.847 .011 & 8.979 .878 \\
\hline $\begin{array}{l}\text { Debit } \\
\text { Kartu } \\
\text { debet }+ \\
\text { kredit }\end{array}$ & 98.638 .287 & 112.948 .818 & 27.786 .999 & 155.663 .442 & 152.482 .094 & 174.445 .472 \\
\hline
\end{tabular}

Sumber: Bank Indonesia (2019a)

Berdasarkan Tabel 3 menunjukkan bahwa secara umum terjadi peningkatan pengguna APMK baik kartu kredit maupun kartu debit. Banyak pengguna yang memiliki kedua kartu yaitu kartu debit dan kartu kredit dibandingkan pengguna yang hanya memiliki salah satu diantara kartu tersebut. Selain itu, bahwa pengguna kartu kredit lebih banyak dibandingkan pengguna kartu debit.

\section{Keunggulan dan Kelemahan Mesin Atm Sistem Konvesional dan Sistem Pengenalan Sidik Jari dan Wajah}

Tabel 4. Perbandingan ATM Konvensional dengan ATM Sidik Jari dan Wajah

\begin{tabular}{|l|l|l|}
\hline No & \multicolumn{1}{|c|}{ ATMKonvesional ( Kartu ) } & ATMSidik Jari dan wajah \\
\hline 1 & $\begin{array}{l}\text { Tingkat keamanan data nasabah } \\
\text { mudah diretas dengan alat } \\
\text { skimmer }\end{array}$ & $\begin{array}{l}\text { Keamanan Data Nasabah terjamin } \\
\text { tingkat akurasi 99\% tidak dapat di } \\
\text { salahgunakan }\end{array}$ \\
\hline 2 & $\begin{array}{l}\text { Kartu ATM Sering hilang, tusak, } \\
\text { Tertelan }\end{array}$ & Lebih Praktis dalam penggunaan \\
\hline 3 & $\begin{array}{l}\text { Tidak Semua Mesin ATM } \\
\text { Menerima jenis kartu }\end{array}$ & $\begin{array}{l}\text { Mesin ATM semua provider Bank } \\
\text { menerima }\end{array}$ \\
\hline 4 & $\begin{array}{l}\text { Pengungkapan kasus } \\
\text { cyberbanking fraud lebih lambat }\end{array}$ & $\begin{array}{l}\text { Memudahkan aparat kepolisian } \\
\text { ungkap kasus perbankan }\end{array}$ \\
\hline
\end{tabular}

Selain kelemahan yang di paparkan pada tabel diatas metode konvesional menggunakan kartu atm memiliki kelemahan lain yang ditemukan pada mesin ATM sistem konvesional menggunakan yaitu dapat dilakukan peretasan data nasabah melalui struk ATM. Seringkali nasabah perbankan membuang struk ATM ke tempat sampah di samping mesin tanpa memusnahkan dengan cara menyobek kertas struk hasil penarikan tunai. Padahal di dalam struk ATM tersebut memuat informasi yang sangat penting seperti informasi saldo, tiga digit angka belakang nomor rekening yang dapat di manfaatkan pelaku kejahatan perbankan menguras isi saldo dengan membuat buku rekening palsu dengan cara mencuri data kependudukan melalui data pemilih milik komisi pemilihan umum [12].

Kelemahan lain yaitu pada kartu ATM yang tersimpan di dalam dompet sangat rawan hilang ataupun kecopetan. Proses pengurusan kartu ATM baru memerlukan proses yang tidak mudah yang telah diatur oleh standar operasional prosedur perbankan dalam mekanisme kartu 
ATM hilang. Salah satu saratnya adalah surat kehilangan kepolisian, data data kependudukan pendukung dan lain sebagainya. Tidak semua mesin ATM bisa menerima semua kartu ATM yang telah di terbitkan pihak perbankan untuk melakukan transaksi pada mesin. Kalaupun bisa di kenakan biaya tambahan administrasi untuk transaksi kartu ATM yang berbeda. Hal ini sangat merepotkan nasabah dalam bertransaksi karena belum terintegrasinya sistem perbankan [13].

Kelemahan lain yang di timbulkan saat transaksi perbankan menggunakan metode konvesional atau kartu debit dan kredit yaitu sangat rentan peretasan pada saat bertransaksi secara digital melalui situs e-commerce [14]. Cara pelaku kejahatan hacker menginput virus malware ke dalam situs e-commerce dengan tujuan mencuri data nasabah perbankan saat melakukan transaksi pembayaran. Saat memasukan nomor kartu debet atau kredit dengan cara membaca tiga digit nomor CVV card verification value di belakang kartu yang menyimpang data data penting nasabah. Disamping itu, transaksi menggunakan sistem kartu sangat rawan mengalami kerusakan pada pita magnetic yang terdapat pada belakang kartu misalnya mengalami goresan, maupun kartu patah dan kemungkinan hilang bersama dompet merupakan beberapa kelemahan bertransaksi menggunakan kartu debit maupun kredit saat ini. Adapun upaya pihak perbankan untuk mengurangi transaksi kartu dengan cara mengalihkan pembayaran menggunakan mobile banking dan berkejasama dengan aplikasi fintech untuk pembayaran secara virtual yang lebih aman karena dilengkapi dengan sistem otentifikasi transaksi

Kelemahan lain yang di temukan pada mesin ATM sistem konvesional menggunakan kartu dapat dilakukan peretasan data nasabah melalui struk ATM. Seringkali nasabah perbankan membuang struk ATM ke tempat sampah di samping mesin tanpa memusnahkan dengan cara menyobek kertas struk hasil penarikan tunai. Padahal di dalam struk ATM tersebut memuat informasi yang sangat penting seperti informasi saldo, tiga digit angka belakang nomor rekening yang dapat di manfaatkan pelaku kejahatan perbankan menguras isi saldo dengan membuat buku rekening palsu dengan cara mencuri data kependudukan melalui data pemilih milik komisi pemilihan umum [15].

\section{Sistem Operasional Mesin Anjungan Tunai Mandiri dengan Menggunakan Sidik Jari dan Pengenalan Wajah Face Reconigtion}



Gambar 2. Ilustrasi Prototype Mesin Indetifikasi ATM Sidik jari dan Wajah

Dari ilustrasi diatas ATM menggunakan pengenalan sidik jari dan wajah memiliki bagian bagian sebagai berikut:

1. Camera Face recognition: yang berfungsi mencapture wajah user dan membandingkan dengan database tersimpan pada sistem perbankan yang terkoneksi dengan rekening. 
2. Keypad: yang berfungsi untuk memasukan kode personal indetification number setelah sistem mengenali wajah dan sidik jari nasabah perbankan

3. Dispenser uang: yang berfungsi mengeluarkan uang nasabah perbankan jika memilih opsi penarikan tunai

4. Pemindai sidik jari: yang berfungsi untuk mengenali sidik jari nasabah jika proses pengenalan wajah diterima oleh sistem perbankan

5. Lock Brankas / Kunci: yang berfungsi untuk mengunci brankas penyimpanan uang.

Sistem Kerja mesin anjungan tunai mandiri menggunakan sidik jari dan pengenalan wajah di bagi menjadi dua kelompok yang pertama proses perekaman dikantor bank dan yang kedua cara menggunakan mesin ATM setelah selesai melakukan proses perekaman di bank yang akan di jelaskan sebagai berikut:

1. Langkah langkah melakukan perekaman ke kantor bank :

a. Nasabah membawa kartu tanda penduduk dan buku rekening tabungan

b. Petugas bank menverifikasi data nasabah dan melakukan sikronisasi kedalam sistem.

c. Nasabah dilakukan pengambilan foto menggunakan kamera khusus pendeteksi wajah dan perekaman sidik jari

d. Data sidik jari dan wajah yang berhasil terekam di validasi ke sistem E-KTP atau database kependudukan nasional

e. Jika proses validasi terdapat kecocokan data, sistem kependudukan nasional mengirimkan notifikasi approved ke bank bersangkutan.

f. Proses perekaman selesai dan nasabah dapat bertrasaksi ke mesin ATM tanpa menggunakan kartu cukup sidik jari dan wajah.

2. Langkah- langkah menggunakan mesin anjungan tunai mandiri :

a. Nasabah memasuki bilik ATM dan memilih opsi scan wajah dan sidik jari

b. Jika sistem mengenali wajah dan sidik jari mesin meminta memasukan keamanan tambahan yaitu nomor pin. Personal identification number

c. Setelah proses completed sistem memberikan akses ke rekening nasabah

d. Nasabah melakukan transaksi di mesin anjungan tunai mandiri

e. Jika proses transaksi sudah selesai nasabah menekan tombol logout pada mesin. Secara otomatis tampilan berubah ke halaman utama

f. Proses transaksi selesai.

3. Fungsi diterapkan mesin anjungan tunai mandiri berbasis pengenalan wajah dan sidik jari :

a. Menghindari kartu ATM tertelan dan penyalahgunaan kartu ATM untuk tindak kejahatan penipuan perbankan.

b. Memudahkan pelacakan pelaku keahatan perbankan oleh pihak kepolisian jika terjadi kejahatan cyber karena memuat informasi biometrics wajah dan sidik jari

c. Memberikan keamanan dan kepraktisan nasabah dalam bertrasaksi pada mesin atm.

d. Menghindari nasabah mempunyai banyak rekening perbankan dalam satu kartu indetitas kependudukan yang berpotensi untuk tindak kejahatan korupsi dengan cara memecah uang kesemua rekening bank.

\section{CONCLUSION}

Pemakainya kartu pada saat bertransaksi menggunakan mesin ATM sangat mempunyai resiko menjadi korban peretasan data nasabah dengan menggunakan alat skimmer. Para hacker mudah dalam membaca data kartu ATM melalui pita magnetic dan chip yang ada di belakang kartu ATM yang berpotensi terkurasnya saldo tabungan. Kekurangan lain kartu ATM mempunyai resiko lain seperti tertelan pada mesin, hilang karena jatuh dan kecopetan, dan rusak karena terendam air dan sebab lain. Kelemahan penggunaan kartu ATM tidak dapat dilakukan untuk bertrasaksi di semua mesin ATM merchant atau provider perbankan lain jikalau bisa di kenakan tarif administrasi tertentu saat bertrasaksi dengan menggunakan kartu 
ATM berbeda.

Sistem pengenalan sidik jari dan wajah atau yang lebih di kenal istilah face reconigtion merupakan sistem keamanan dengan akurasi yang tinggi dan tidak dipalsukan. Sidik jari melekat kuat pada ciri biometrik individu yang terbentuk dari trimester pertama kehamilan sampai seumur hidup dengan memiliki karakteristik dan pola yang tetap bisa berubah kecuali andanya trauma atau cidera. Sistem ini telah diterapkan sebelumnya untuk mesin presensi, pengamanan pintu, brankas dan indetifikasi penyakit bawaan dan terbukti significant dalam penerapanya dengan rata rata akurasi mencapai 80-99 \%. Oleh sebab itu, sangat relevant untuk pengamanan mesin anjungan tunai mandiri dengan alasan selain memudahkan nasabah atau user dalam bertrasaksi di mesin ATM juga melindungi data nasabah dari tindak kejahatan cyberbanking yang sangat merugikan baik dari pihak nasabah maupun pihak institusi perbankan.

\section{REFERENCES}

[1] D.A. Setiawan, Perkembangan Modus Operandi

[2] L. Hakim, Kerugian Skimming BRI Rp 2,7 Miliar. https://radarlombok.co.id/kerugianskimming-bri-rp-27-miliar.html, diakses 9 Juni 2019.

[3] P. Choirina, R.A. Asmara, Deteksi Jenis Kelamin berdasarkan Citra Wajah Jarak Jauh dengan Metode Haar Cascade Classifier, J. Inform. Polinema. (2016).

[4] I.K.S. Widiakumara, I. Putra, Aplikasi Identifikasi Wajah Berbasis Android, Lontar Komputer. (2018).

[5] A.S. Rafika, M. Budiarto, W. Budianto, Aplikasi Monitoring Sistem Absensi Sidik Jari. (2014) 134-146.

[6] A. Ightikoma, Variasi Sidik Palmar dan Phalanx Distal pada Penderita Kanker Payudara di Surabaya. (2017).

[7] M.A. Rahman, I.S. Wasista, M. Kom, L. Belakang, Sistem Pengenalan Wajah Menggunakan Webcam untuk Absensi dengan Metode Template Matching, Elektronika. $1-6$.

[8] D.Y. Liliana, M.A. Rahman, Deteksi Wajah Manusia pada Citra Menggunakan Dekomposisi Fourier, J. Sci. Model. Comput. (2013) 14.

[9] G. Ramadhan, E.C. Djamal, T. Darmanto, Klasifikasi Identitas Wajah untuk Otorisasi Menggunakan Deteksi Tepi dan LVQ, Semin. Nas. Apl. Teknol. Inf. (2016) 37-41.

[10] E. Sudarmilah, Pengenalan wajah dengan perbandingan Histogram, Semin. Nas. Apl. Teknol. Inf. (2009).

[11] A. Dewi, B. Hidayat, J. Arif, Identifikasi Ras Manusia Berdasarkan Citra Wajah Berbasis Discrete Wavelet Transform dan Learning Vector Quantization-Neural Networks, Pros. SENIATI. (2019).

[12] W. Firmandani, M. Malik, Kendala Manajemen Risiko Teknologi Informasi pada Kasus Skimming ATM Bank X, J. ILMU Manaj. DAN BISNIS. 107-120.

[13] L.T. Panjaitan, Analisis Penanganan Carding dan Perlindungan Nasabah dalam Kaitannya dengan Undang-Undang Informasi dan Transaksi Elektronik no. 11 Tahun 2008, J. Telekomun. dan Komput. 1.

[14] M.R.H. Rumman, A. Sarker, M.M. Islam, M.I. Hoque, R. Kuri, ATM Shield: Analysis of Multitier Security Issues of ATM in the Context of Bangladesh, J. Exp. Sci. (2020) 2227.

[15] Y.M. Rihi, A.J. Santoso, I. Wisnubadhra, Menggunakan Verifikasi Sidik Jari Life Fingerprint. (2013) 31-38. 